\title{
Methodology study on voluntary emission reduction of greenhouse gases in port off road mobile machinery hybrid power transformation project
}

\author{
Guo $\mathrm{xu}^{*}$ \\ Key Laboratory of Environmental Protection in Water Transport Engineering Ministry of Communications, \\ Tianjin Research Institute of Water Transport Engineering, Tianjin 300456, China
}

\begin{abstract}
The greenhouse gas emissions of ports mainly come from the combustion of fossil fuels produced in the loading and unloading production. With the continuous advancement of port equipment electrification, non road mobile machinery has gradually become the main source of fossil fuel emissions. On the basis of the existing voluntary emission reduction methodology, this paper puts forward the greenhouse gas voluntary emission reduction methodology of port non road mobile machinery hybrid power transformation project, and verifies the correctness of the methodology through examples. In the future, it can be used as the accounting method of trading volume in voluntary carbon emission trading, and effectively promote the energy conservation and emission reduction of port industry and green port construction.
\end{abstract}

\section{Introduction}

The greenhouse gas emissions of ports mainly come from the combustion of fossil fuels produced in the loading and unloading production. With the continuous advancement of port equipment electrification, non road mobile machinery has gradually become the main source of fossil fuel emissions. With the increasingly stringent requirements of greenhouse gas emissions, it is necessary to carry out the hybrid transformation of various machinery to reduce the use of fossil fuels.

On this basis, the market approach to achieve voluntary emission reduction is an important means to improve the initiative of enterprises and improve the effect of emission reduction. At present, China has carried out various carbon trading practices ${ }^{[1-4]}$. For example, Shanghai has incorporated aviation into the carbon trading system, and Shenzhen has adopted the carbon trading mechanism to promote new energy vehicles. At the same time, various experts and scholars have also carried out relevant research, Qian Zhenglin et al. conducted a comparative study on seven international voluntary emission reduction standards, including the gold standard and the Chicago Climate Exchange Standard, from five aspects of basic information, project information, accounting methods, sustainability requirements, verification and registration, and put forward relevant countermeasures and suggestions for the development and standardization of China's voluntary emission reduction market ${ }^{[5]}$. In view of the problems existing in China's voluntary carbon emission reduction market, Ma Qiujun and others put forward countermeasures and suggestions such as establishing emission reduction awareness, building institutional environment, improving the decomposition principle of emission reduction indicators, unifying trading standards, and improving market structure ${ }^{[6]}$.

\section{Introduction of voluntary emission reduction methodology}

\subsection{Definition}

Port non road mobile machinery: all kinds of port operation equipment, such as forklift truck, tire crane, empty container stacker, etc., which are mainly powered by fossil fuel and used for loading, unloading and stacking operations.

Hybrid power transformation: in the case of the original functions of port non road mobile machinery, the energy supply mode is changed from the original high-power diesel generator set to the power supply by the municipal power grid, and only the small power diesel generator set is equipped to provide the power needed for short-distance movement.

Workload: Port non road mobile machinery completes a unit weight of goods handling or overturning and other complete operation process.

\footnotetext{
* Corresponding author: 18630836305@163.com
} 


\subsection{Applicable conditions}

This methodology is applicable to the oil-electricity hybrid transformation of various existing port non road mobile machinery, so as to achieve emission reduction projects (without considering the impact of equipment type and high-voltage and low-voltage frequency conversion in power grid).

\subsection{Baseline scenario}

Baseline emission refers to the multiplication of energy consumption per unit operation volume of port non road mobile machinery, annual average operation volume of single machine and emission coefficient of fuel used by equipment under normal operation conditions. The calculation formula is as follows.

$$
B E_{y}=\sum_{i} E F_{B L, T E U, i} \times D D_{i, y} \times N_{i, y} \times 10^{-6}
$$

$B E_{y}$ : Represents the total emissions from the baseline in year y $\left(\mathrm{tCO}_{2}\right)$.

$E F_{B L, T E U, i}$ : Emission factors for baseline RTG type i $\left(\mathrm{gCO}_{2} / \mathrm{t}\right)$

$D D_{i, y}$ : Average annual work load $(\mathrm{t})$.

$N_{, y}$ : Number of RTG operations.

$E F_{B L, T E U, i}=S F C_{i} \times N C V_{B L, i} \times E F_{B L, i} \times I R^{t}$

$S F C_{i}:$ Fuel consumption rate $(\mathrm{g} / \mathrm{t})$

$N C V_{B L, i}:$ Net calorific value of fossil fuel consumption $(\mathrm{J} / \mathrm{g})$

$E F_{B L, i}:$ Emission factors of fossil fuel consumption $\left(\mathrm{gCO}_{2} / \mathrm{J}\right)$

$I R^{t}$ : The technical improvement factor of baseline RTG in $t$ year. The technical improvement rate is applied to each calendar year, and the default value of technical improvement factor is 0.99 for all RTG types of baseline. $t$ : Years of technical improvement.

\subsection{Emission calculation}

Project emissions: including emissions from fossil fuel consumption of port non road mobile machinery, calculated as follows:

$$
P E_{y}=\sum_{i} E F_{P /, T E U, i, y} \times D D_{i, y} \times N_{i, y}
$$

$P E_{y}:$ Total project emissions $\left(\mathrm{tCO}_{2}\right)$

$E F_{P /, T E U, i, y}$ : Emission factor of unit work volume $\left(\mathrm{tCO}_{2} / \mathrm{t}\right)$

$N_{i, y}$ : Number of RTGs

$D D_{i, y}$ : Average annual work load

The emission factor is calculated as follows:

$$
\begin{aligned}
E F_{P l, T E V, L, y} & =\sum_{i} S E C_{P l, T E V, i, y} \times \frac{E F_{\text {elect }, y}}{1-T D L_{y}} \times 10^{-3} \\
& +\sum_{i} S F C_{P J, T E V, i, y} \times N C V_{P J, i} \times E F_{P J, i} \times 10^{-6}
\end{aligned}
$$

$S E C_{P J, T E U, i, y}$ : Power consumption rate per unit work load $(\mathrm{kWh} / \mathrm{t})$.

$E F_{\text {elect }, y}: \mathrm{CO}_{2}$ emission factor of power consumption $\left(\mathrm{kgCO}_{2} / \mathrm{kWh}\right)$.

$S F C_{P J, T E U, i, y}$ : Fossil fuel consumption rate per unit operation volume $(\mathrm{g} / \mathrm{t})$.

$E F_{P_{l, i},}: \mathrm{CO} 2$ emission factors of fossil fuels $\left(\mathrm{gCO}_{2} / \mathrm{J}\right)$.

$N C V_{P /, i}:$ Net calorific value of fossil fuel consumption $(\mathrm{J} / \mathrm{g})$.

TD $L_{y}$ : Average loss of technical transmission and distribution of electricity.

\section{Example calculation}

\subsection{Baseline emission calculation}

The emission factors of fossil fuels are as follows:

$20.2 \mathrm{t}-\mathrm{C} / \mathrm{TJ} * 44 / 12=74.067 \mathrm{~g}-\mathrm{CO}_{2} / \mathrm{MJ}$

$=74.067 * 10^{-6} \mathrm{~g}-\mathrm{CO}_{2} / \mathrm{J}$

The net calorific value of fossil fuel consumption is $42652 \mathrm{j} / \mathrm{g}$, the technical improvement coefficient is 0.93 , and the unit consumption of crane operation is $116 \mathrm{~g} / \mathrm{t}$, then the baseline emission factor is:

$$
\begin{aligned}
E F_{B L_{t} T E U_{i} i} & =S F C_{i} \times N C V_{B L_{r} i} \times E F_{B L_{i} i} \times I R^{t} \\
& =116 * 74.067 * 10-6 * 42652 * 0.93 \\
& =341 \mathrm{~g}-C 0_{2} / t
\end{aligned}
$$

If the annual operation capacity of the company's revamped equipment is $41588030 t$, the baseline emission is:

$$
\begin{aligned}
B E_{y} & =F_{B L, T E U, i} \times D D_{i, y} \times N_{i, y} \times 10^{-6} \\
& =341 \mathrm{~g}-C O_{2} / t * 41588030 t \\
& =14185.59 t-\mathrm{CO}_{2}
\end{aligned}
$$

\subsection{Emission calculation}

The annual operation capacity of the company's crane is $41588030 t$, the fuel consumption is 3723501 , and the diesel density is 0.86 , which is equivalent to $320221 \mathrm{~kg}$, and the power consumption is $4687830 \mathrm{kwh}$. Then the unit consumption is:

$(320221 \mathrm{~kg}+4687830 \mathrm{kWh}) / 41588030 \mathrm{t}$

$=(0.077 \mathrm{~kg}+1.13 \mathrm{kWh}) / \mathrm{t}$

The power emission factor of the port area is 0.7598 t-co2 / MWh, equivalent to $759.8 \mathrm{~kg}-\mathrm{CO}_{2} / \mathrm{kwh}$; the average loss of power technology transmission and distribution is $20 \%$, and the net calorific value of fossil 
fuel consumption is $42652 \mathrm{j} / \mathrm{g}$; the emission factor of fossil fuel is: $0.7598 \mathrm{t}-\mathrm{CO}_{2} / \mathrm{MWh}$, equivalent to $759.8 \mathrm{~kg}-\mathrm{CO}_{2} / \mathrm{kwh}$

$$
20.2 \mathrm{t}-\mathrm{C} / \mathrm{TJ} * 44 / 12=74.067 \mathrm{~g}-\mathrm{CO}_{2} / \mathrm{MJ}=74.067 * 10^{-6} \mathrm{~g}-\mathrm{CO}_{2} / \mathrm{J}
$$

Therefore, the emission factor of the equipment is as follows:

$$
\begin{aligned}
& F_{P, T E U i, y}=\sum_{i} S E C_{P, T, T E, i, y} \times \frac{E F_{\text {Elect }, y}}{1-T D L_{y}} \times 10^{-3} \\
& +\sum_{i} S F C_{P J, T E U, i, y} \times N C V_{P l, i} \times E F_{P J, i} \times 10^{-6} \\
= & 1.13 \mathrm{Kwh} / \mathrm{t} \times\left(759.8 \mathrm{~kg}-\mathrm{CO}_{2} / \mathrm{Kwh}\right) /(1-0.2) \times 10^{-3} \\
& +0.077 \mathrm{~kg} / \mathrm{t} \times\left(42652 \mathrm{~J} / \mathrm{g} \times 74.067 \times 10^{-6} \mathrm{~g}\right. \\
= & 1.03 \mathrm{~kg}-\mathrm{CO}_{2}
\end{aligned}
$$

Then the total annual emission of the project is:

$$
P E_{y}=\sum_{i} E F_{P /, T E U, i, y} \times D D_{i, y} \times N_{i, y}
$$$$
=1.073 \times 41588030=4462 \mathrm{t}
$$

\subsection{Emission calculation}

$$
\begin{aligned}
E R_{y} & =B E_{y}-P E_{y} \\
& =14185.59-4462.40 \\
& =9723.19 \mathrm{t}-\mathrm{CO}_{2}
\end{aligned}
$$

\section{Conclusion}

Port off road mobile machinery is the main source of port greenhouse gas emissions. Based on the existing voluntary

\begin{tabular}{|c|c|c|}
\hline Parameter & description & monitoring method \\
\hline$D D_{i, y}$ & $\begin{array}{l}\text { Average operation volume of equipment } i \\
\text { in the year } y(\mathrm{t} / \text { year) }\end{array}$ & $\begin{array}{l}\text { Mode A: monitor all operating equipment. } \\
\text { Method B: Sampling survey was used for each type. The } \\
\text { sampling of this project shall be randomly selected } \\
\text { according to the latest version of "general provisions for } \\
\text { sampling and investigation of small-scale CDM project } \\
\text { activities", and the sample size shall be determined with } \\
90 \% \text { confidence interval and } \pm 10 \% \text { error. The lower limit } \\
\text { of } 95 \% \text { confidence interval should be used for the driving } \\
\text { distance of annual draw. }\end{array}$ \\
\hline$S E C_{P J, i, y}$ & $\begin{array}{l}\text { By monitoring the oil consumption se of } \\
\text { the equipment and the electricity SF after } \\
\text { transformation, the fossil fuel consumption } \\
\text { / power consumption ( } \mathrm{g} / \mathrm{t} \text { and } \mathrm{kwh} / \mathrm{t} \text { ) per } \\
\text { unit operation volume of RTG type I } \\
\text { project in } y \text { year are obtained. The } \\
\text { corresponding formula is as follows: } \\
\qquad S E C_{P J, i, y}=S E / D D_{i, y} ; \\
\quad S F C_{P J, i, y} S F / D D_{i, y}\end{array}$ & $\begin{array}{l}\text { Mode A: monitor the consumption of all non road mobile } \\
\text { machinery. } \\
\text { Method B: measure the power / fossil fuel consumption per } \\
\text { unit operating capacity of each type of non road mobile } \\
\text { machinery under typical working conditions; sampling shall } \\
\text { be selected randomly according to the latest version of } \\
\text { "general provisions for sampling and investigation of small- } \\
\text { scale CDM project activities", and the sample size shall be } \\
\text { determined with } 90 \% \text { confidence interval and } \pm 10 \% \text { error. } \\
\text { The upper limit of } 95 \% \text { confidence interval should be used } \\
\text { for power / fossil fuel consumption rate. }\end{array}$ \\
\hline$S F C_{P J, I, y}$ & $\begin{array}{l}\text { By monitoring the oil consumption se of } \\
\text { equipment and the electricity } \mathrm{SF} \text { after } \\
\text { transformation, the fossil fuel consumption } \\
\text { / power consumption ( } \mathrm{g} / \mathrm{T} \text { and } \mathrm{kwh} / \mathrm{T}) \\
\text { per unit operation volume of non road } \\
\text { mobile machinery of project type } i \text { was } \\
\text { obtained. The corresponding formula is: } \\
\qquad S E C_{P J, i, y} S E / D D_{i, y} ; \\
\qquad F C_{P J, i, y} S F / D D_{i, y ;}\end{array}$ & $\begin{array}{l}\text { Mode A: monitoring the consumption of non road mobile } \\
\text { machinery in all projects } \\
\text { Method B: measure the power / fossil fuel consumption per } \\
\text { unit operating capacity of each type of non road mobile } \\
\text { machinery under typical working conditions; the sample size } \\
\text { shall be determined by } 90 \% \text { confidence interval and } \pm 10 \% \\
\text { error according to the latest version of "general provisions } \\
\text { for sampling and investigation of small-scale CDM project } \\
\text { activities". The upper limit of } 95 \% \text { confidence interval } \\
\text { should be used for power / fossil fuel consumption rate. }\end{array}$ \\
\hline$E F_{\text {elec }}$ & $\begin{array}{l}\text { Grid } \mathrm{CO}_{2} \text { emission factors for type } i \text { non } \\
\text { road mobile machinery }\end{array}$ & According to the methodology cms-002-v01 / cms-003-v01 \\
\hline
\end{tabular}
emission reduction methodology, this study proposes the greenhouse gas voluntary emission reduction methodology of port off road mobile machinery hybrid power transformation project, and verifies the correctness of the methodology through examples. It can be used as the accounting method of trading volume in voluntary carbon emission trading in the future, and can be effectively promoted Energy saving and emission reduction of port industry and green port construction.

Table 1. Parameters to be monitored 


\section{References}

1. Liu L L etc, Study on methodology of voluntary emission reduction of greenhouse gases from shore power projects (journal of waterway and harbor), 445-449,2019,40(4).

2. Guo X etc, Research on construction technology of energy consumption onlinemonitoring system for port energy equipment. (journal of waterway and harbor), 746-752,2018,39(6).

3. WANG C Y etc,Components of regional emergency linkage system for ship pollution accidents ,(journal of waterway and harbor), 340-346,2020,41(3).

4. XIONG H X etc. Enlightenments of Tokyo bay revitalization action plan (2003 2012) in Janpan to Bohai bay in China.( journal of waterway and harbor) 119-124, 2020,41(1).

5. Qian Z L,Ma X M. A comparative study of international voluntary emission reduction standards (Eco economy) 39-42,48,2012,(5).

6. Ma Q J,Liu X. Countermeasures for the development of China's voluntary carbon emission reduction market(economic review) 58-61.2011,(11). 